Biografien kan på mange måter deles i to: Den første delen omhandler familiemannen og gründeren, forretningsmannen og aristokraten i siste halvdel av 1700tallet. Den siste delen er preget av politikeren og nasjonsbyggeren fra 1812 og frem til sin død. Første del er preget av å være skrevet av faghistorikeren, detaljene er uendelige og henvisningene likeså. Man kjemper seg gjennom slektstavler og forretningsbrev, side opp og side ned med perifere navn og selskapeligheter. Men så: Under opptakten til Eidsvoll og 1814 blir boken spennende og fortellende. Undertegnede har ikke lest noe tilnærmelsesvis mer interessant om de politiske bølgene som Kiel-traktaten avstedkom i Norge, de motsetningene som hersket på Eidsvoll, og de problemene som oppsto i unionen med Sverige, og konfrontasjonen med en sterk og maktglad Carl Johan.

For faghistorikere - og lesere med spesiell interesse for lokalhistorie i Oslo og Bærum - er første del sikkert uvurderlig som kildeskrift. Boken er da også sponset av Bogstad Gårds Venneforening. Den siste delen er glitrende, spennende og interessant. Her er det også et vell av detaljer og til dels morsomme anekdoter, men fortellingen glir uhindret av henvisningene. For historieinteresserte lesere som ønsker en innføring i politikken rundt 1814 , er siste del en opplevelse.

Resten er for faghistorikerne.

\section{Ragnar Stien}

Oslo

\section{Litteratur}

1. Stien R. «- det skjønneste Sprog ere forenede med hans overordentlige Naturgaver». Anmeldelse av: Holck P. Bernt Anker - samtid, liv og forfatterskap. Tidsskr Nor Lægeforen 2006; 126: 3339-40.

\section{Visdom er målet!}

Einhorn S

Veier til visdom

171 s. Oslo: Cappelen Damm, 2010.

Pris NOK 299

ISBN 978-82-02-32253-3

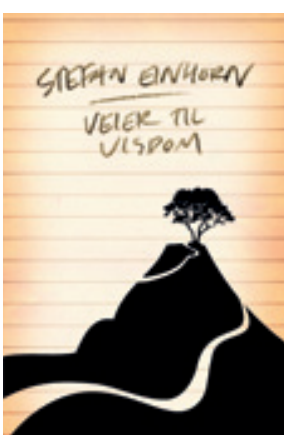

Forfatteren er overlege ved Radiumhemmet i Stockholm og professor i etikk ved Karolinska Institutet. Han føler at vi som mennesker har fire oppgaver: å søke etter sannheten, å leve etter etikkens bud, å elske våre medmennesker og å vinne frem til visdom. Denne boken handler om den fjerde oppgaven - visdommen.

De sju kapitlene omhandler de forskjellige sidene ved visdom og hvorledes vi kan vinne visdom gjennom livet. Forfatteren definerer visdom som: «en dømmekraftig, omtenksom og pragmatisk evne til aktivt å forholde seg til viktige spørsmål som ikke har noe entydig svar». Visdom handler ofte om å finne løsninger på problemer. Det er vanskelig, og det er lett å gjøre feil. Den vise har ydmykhet til å erkjenne feil og lære av dem. Derfor tar det tid å vinne frem til visdom, og det er en kobling mellom alder, erfaring og visdom.

Forfatteren bygger på en omfattende lesing av historie, filosofi, religion og etikk. Han drøfter både den positive visdommen og den negative dumheten, og kanskje kan den avgjørende forskjellen sammenfattes i denne setningen fra Talmud: «Den vise søker visdommen, den dumme tror han har funnet den.» Vanlige hindringer på veien til visdom er skråsikkerhet, fanatisme eller til og med fundamentalisme, sinne, forutinntatthet og egeninteresse. Den vise er også god mot sine medmennesker. I en av sine tidligere bøker, Kunsten å vare snill (1), skriver forfatteren at det lønner seg å være snill, for da er andre snille mot deg.

Forfatteren skriver godt, og teksten er full av tankevekkende historier og sitater. Oversettelsen fra svensk er god. En liten svakhet er at det mangler både fullstendige litteraturreferanser og et stikkord- og personregister. Derfor er det ikke så lett å finne tilbake til de stedene man gjerne vil tenke mer over.

Hvem kan ha nytte av denne boken? Det selvfølgelige svaret er: alle. Men den er spesielt viktig for leger fordi de stadig må håndtere vanskelige problemer uten skråsikkerhet, men med forståelse og godhet. Leger må daglig kjempe med et paradoks: Vi skal kunne faget vårt og føle oss trygge på denne kunnskapen. Men den skal brukes til å hjelpe medmennesker i situasjoner som ofte ikke har noen god løsning. Den vise kan håndtere slike dilemmaer på en god måte, og jeg tror denne teksten kan være en god hjelp.

\section{Peter F. Hjort}

Blommenholm

\section{Litteratur \\ 1. Einhorn S. Kunsten å være snill. Oslo: Forlaget Lille Måne AS, 2006.}

\section{Litt annerledes om psykiatri}

Skårderud F, Haugsgjerd S, Stänicke E. Psykiatriboken

Sinn-kropp-samfunn. 538 s, tab, ill. Oslo: Gyldendal Akademisk, 2010. Pris NOK 495 ISBN 978-82-05-38027-1

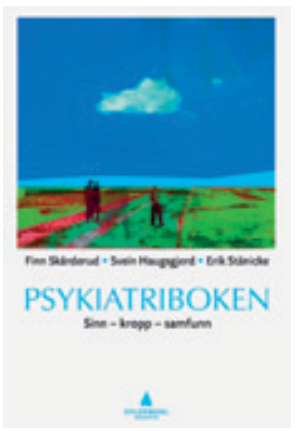

Ifølge forfatterne er dette en lærebok i psykiatri for helse- og sosialarbeidere som har psykisk helse som virksomhet, og som er relevant for en rekke profesjonsstudier og profesjoner. Forfatterne har knyttet til seg ni medarbeidere som har utarbeidet hver sine kapitler på bakgrunn av sin ekspertise. De tre hovedansvarlige har ønsket at boken som helhet skal vektlegge samtalebehandling i forskjellige former.

Del 1 handler om feltet: definisjoner, helsearbeideren, psykiatriens historie og forskjellige forståelsesformer, del 2 om undersøkelse og behandling, og del 3 omhandler de forskjellige lidelsene, hvor det også er ispedd noen behandlingsaspekter. Beskrivelsen av lidelsesformene (personlighetsforstyrrelser, angstlidelser, psykotiske tilstander osv.) begynner først på side 269 . Det betyr at nybegynnere som leser boken fortløpende, vil lese om behandling av noe de ikke skjønner hva er.

Styrken er en fornuftig integrasjon av filosofiske, kulturelle, psykologiske og relasjonelle aspekter ved psykiatriske fenomener, slik som det særlig kommer frem under temaene spiseforstyrrelser og selvskading. Mentaliseringsbasert tilnærming, som handler om hjelp til å se oss selv utenfra og andre innenfra og derigjennom forstå oss selv og andre, er også fremstilt på en klinisk nyttig måte. Forfatterne er skeptiske til manualiserte intervensjoner som er lette å lære, og som ukritisk anbefales samtidig som klinisk skjønn og erfaring neglisjeres. Dette er ifølge forfatterne en fare ved kognitiv terapi, men selv undervurderer de betydningen av kompetanse og erfaring ved utøvelse av farmakoterapi. De skriver f.eks. at medikamentell behandling ved psykotiske tilstander ikke krever noen stor innsats i tid. I dag legges det imidlertid mye vekt på saklig informasjon om psykofarmakas virkninger og bivirkninger og betydningen av etterlevelse av behandlingsråd. Dette krever en god terapeutisk allianse som forutsetter både psykologisk og biologisk kompetanse, tålmodighet og mye tid. Forfatterne virker ambivalente til farmakoterapi og legger for stor vekt på legemiddelindustriens propaganda, bivirkninger av medikamentene og advarsler mot bruk. I tillegg er retningslinjene for riktig anvendelse, slik som de beskrives i boken, mangelfulle. 